\title{
Identification of the Best Model for Forecasting of Sugar Production among Linear and Non-linear Model
}

\author{
J. Megha*, Y.N. Havaldar, N.L. Pavithra, B.B. Jyoti and V. Kiran Kumar \\ University of Agriculture Sciences, Dharwad, Krishinagar, \\ Dharwad-580005, Karnataka, India \\ *Corresponding author
}

\section{A B S T R A C T}

\begin{tabular}{|l|}
\hline Ke y w or d s \\
$\begin{array}{l}\text { Sugar Production } \\
\text { Linear and Non- } \\
\text { linear Model }\end{array}$ \\
\hline Article Info \\
\hline $\begin{array}{l}\text { Accepted: } \\
\text { 26 February } 2019 \\
\text { Available Online: } \\
\text { 10 March } 2019\end{array}$ \\
\hline
\end{tabular}

The present study "Identification of the best model for forecasting of sugar production among linear and non-linear model." emphasis on the factors affecting production of sugar in India as sugar is one of the most important commodities; produced and consumed around the world. India is the 2nd largest producer of sugar in the world next to Brazil and also largest consumer of sugar. Time series data on sugar production and sugarcane area and production was collected from the year 1990-91 to 2015-16. Linear and non-linear models were used to identify the best model for forecasting of sugar production. Among all models selected the compound model was found to be best fit with highest $\mathrm{R}^{2}$, minimum root mean square error and standard error. The cubic and linear models were also showed significantly best fit for predicting the sugar production based on sugarcane area. The cubic model was found to be best fit with highest $\mathrm{R}^{2}$, minimum mean square error and standard error. Linear model was also found to be the best fit for predicting sugar production by sugarcane production.

\section{Introduction}

Sugar is one of the most important commodities; produced and consumed around the world. Sugar is produced in over 123 countries worldwide but over 70 per cent of world sugar production is consumed domestically and the remaining is traded in the world. India is the second largest producer of sugar in the world having a share of over 16 per cent of world's sugar production next to Brazil having share of 22 per cent and also largest consumer of sugar. Sugar is derived mainly from sugarcane and sugar beet.
Around 80 per cent of sugar is derived from sugar cane and is largely grown in tropical countries. The remaining 20 per cent comes from sugar beet grown mainly in the temperate zones in the North. In general, the costs of producing sugar from sugar cane are lower than that of sugar beet.

In India, sugar industry has two major areas of concentration. One comprises Uttar Pradesh, Bihar, Haryana and Punjab in the north and the other states are Maharashtra, Karnataka, Tamil Nadu and Andhra Pradesh in the south. 
Karnataka has 30 mills producing 1,151 thousand tonnes or over 6 per cent of the total sugar production of India. Belgaum and Mandya districts have the highest concentration of sugar mills. Bijapur, Bellary, Shimoga and Chittradurga are the other districts where sugar mills are scattered.

The key feature of a statistical model is that variability is represented using probability distributions, which form the building-blocks from which the model is constructed.

In the present study, taking as area and production of sugarcane in India as independent variables and sugar production as dependent variable, non-linear and polynomial models were attempted.

\section{Materials and Methods}

Area and production of sugarcane and sugar production data was collected from 1990 to 2015. The required data to satisfy the specific objectives of the present study were collected from different sources namely viz., India's sugar trade: A fresh look by Deokate tai balasaheb. Commodity profile for sugar, January 2016 and www.indiastat.com.

The simplest way of representing any relation is by fitting a linear equation using the variables under study. But, in all the cases it may not follow linear relationship. In the present study, taking as area and production of sugarcane in India as independent variables and sugar production as dependent variable, non-linear and polynomial models were attempted (Gomez and Gomez 1958). Following models fitted to the data.

\section{Linear model}

$\mathrm{Y}=\mathrm{b}_{0}+\mathrm{b}_{1}(\mathrm{x})$ is the linear form of the model. $\mathrm{Y}$ and $\mathrm{x}_{\mathrm{i}}{ }^{6} \mathrm{~s}$ are sugar production and sugarcane area/sugarcane production period respectively. $\mathrm{b}_{0}$ and $\mathrm{b}_{\mathrm{i}}{ }^{\text {'s }} \mathrm{s}$ are constants to be estimated

\section{Logarithmic model}

The linear form of the model is:

$\mathrm{Y}=\mathrm{b}_{0}+\mathrm{b}_{1} \ln (\mathrm{x})+\square_{\mathrm{i}}$

$Y_{i}$ is dependent variable and $X_{i}$ 's are independent variables.

$b_{i}$ 's are constants (where $\mathrm{i}=0 \quad \& 1$ ) to be estimated and $\ln$ is natural $\log$ and $\square_{\mathrm{i}}$ is the random error

\section{Quadratic model}

The form of the equation is:

$\mathrm{Y}=\mathrm{b}_{0}+\mathrm{b}_{1} \mathrm{x}+\mathrm{b}_{2} \mathrm{x}^{2}+\square_{\mathrm{i}}$

Where,

$\mathrm{Yi}$ is dependent variable and $\mathrm{x}_{\mathrm{i}}{ }^{\prime} \mathrm{s}$ are independent variables.

bi's are constants (where $\mathrm{i}=0,1 \quad \& 2$ ) to be estimated and $\square_{i}$ is the random error.

The quadratic model was used to model a series that take off or a series that dampens.

\section{Cubic model}

Here the equation is:

$\mathrm{Y}=\mathrm{b}_{0}+\mathrm{b}_{1} \mathrm{x}+\mathrm{b}_{2} \mathrm{x}^{2}+\mathrm{b}_{3} \mathrm{x}^{3}+\square_{\mathrm{i}}$

$\mathrm{Y}$ is dependent variable and $\mathrm{x}_{\mathrm{i}}$ 's are independent variables.

bi's are constants (where $i=0,1,2 \& 3$ ) to be estimated and $\square_{\mathrm{i}}$ is the random error.

\section{Exponential model}

Model under consideration is:

$\mathrm{Y}=\mathrm{b}_{0} * \mathrm{e}^{(\mathrm{bl} 1 * \mathrm{x})}+\square_{\mathrm{I}} \quad$ or

$\ln (\mathrm{Y})=\ln \left(\mathrm{b}_{0}\right)+\left(\mathrm{b}_{1} * \mathrm{x}\right)$ where, 
$\mathrm{Y}_{\mathrm{i}}$ is dependent variable and $\mathrm{x}_{\mathrm{i}}{ }^{\prime} \mathrm{s}$ are independent variables.

$b_{i}$ 's are constants (where $i=0, \& 1$ ) to be estimated and $\ln$ is natural log and " $\square$ " " is the exponential function

\section{Growth model}

It has the form:

$\mathrm{Y}=\mathrm{e}^{\left(\mathrm{b} 0+\left(\mathrm{b} 1^{*} \mathrm{x}\right)\right)}+\square_{\mathrm{i}}$

On transformation,

$\ln (\mathrm{Y})=\mathrm{b}_{0}+\left(\mathrm{b}_{1}{ }^{*} \mathrm{x}\right)$ which is a linear form of the model.

$\mathrm{Y}$ dependent variable and $\mathrm{x}_{\mathrm{i}}$ 's are independent variables.

$b_{i}$ is a constant to be estimated, $i=0,1$ and $\ln$ is natural $\log$ and " $\square$," is the exponential function.

\section{Compound model}

It has the form:

$\mathrm{Y}=\mathrm{b}_{0} \mathrm{~b}_{1}{ }^{\mathrm{x}}$

On transformation,

$\ln (\mathrm{Y})=\ln \left(\mathrm{b}_{0}\right)+(\mathrm{x}) \ln \left(\mathrm{b}_{1}\right)$ is obtained which is of the linear form

where,

$\mathrm{Y}$ is dependent variable and $\mathrm{x}_{\mathrm{i}}{ }^{\prime} \mathrm{s}$ are independent variables.

$b_{i}$ is a constant to be estimated, $i=0,1$ and $\ln$ is natural $\log$.

\section{Results and Discussion}

From the non-linear model regression analysis, it is evident that, different models used to predict sugar production with the help of sugarcane area. For predicting sugar production with respect to sugarcane area, all the models were found to be significant.
Among all models selected the compound model was found to be best fit with highest $R^{2}$ (co-efficient of determination) of 93.3 per cent, minimum root mean square error of 0.30 and standard error of 0.094 .

The cubic and linear model was also showed significantly best fit for predicting the sugar production with co-efficient of determination $\left(\mathrm{R}^{2}\right)$ of 92.8 per cent and 92.2 per cent respectively where as the standard error and the root mean square was quite high compared to Compound model.

Linear model was also found to be good fit as it is easy for prediction.

Compound model ${ }^{\widehat{y}}=16.754 * 1.714^{\mathrm{x}}$

$\mathrm{y}=$ sugar production.

$\mathrm{x}=$ sugarcane area.

The results revealed that, different linear and non-linear models used to predict sugar production with the help of sugarcane production. For predicting sugar production with sugarcane production, all the models were significant. Among these models cubic model was found to be best fit with highest $\mathrm{R}^{2}$ (co-efficient of determination) of 91.6 per cent, minimum mean square error and standard error of 0.103 and 0.10 respectively.

The quadratic and linear model were also showed significantly best fit for predicting the sugar production with co-efficient of determination $\left(\mathrm{R}^{2}\right)$ of 91.6 per cent and 90.4 per cent respectively where as the standard error and the root mean square were quite high compared to Cubic model that is the standard error and RMSE was 0.11 and 18.99 for quadratic and for linear it was 0.104 and 0.15 respectively. Irrespective of this linear model was also found to be good fit (Table 1 and 2; Fig. 1 and 2). 
Table.1 Statistical models for predicting the sugar production in India

\begin{tabular}{|l|l|c|c|c|}
\hline \multicolumn{1}{|c|}{ Model } & \multicolumn{1}{|c|}{ Equation } & \multicolumn{1}{c|}{$\mathbf{R}^{2}$} & $\begin{array}{c}\text { Standard } \\
\text { error }\end{array}$ & RMSE \\
\hline Linear & $\widehat{y}=-232.579+95.52 \mathrm{x}$ & 0.922 & 0.095 & 15.47 \\
\hline Logarithmic & $\widehat{y}=-412.270+406.96 \log (\mathrm{x})$ & 0.907 & 16.86 & 6.10 \\
\hline Growth & $\widehat{y}=\mathrm{e}^{(16.754+0.539 \mathrm{x})}$ & 0.909 & 0.093 & 0.305 \\
\hline Cubic & $\widehat{y}=-26.46-23.116 \mathrm{x}+1.262 \mathrm{x}^{3}$ & 0.928 & 15.01 & 0.42 \\
\hline Quadratic & $\widehat{y}=68.051-44.914 \mathrm{x}+16.143 \mathrm{x}^{2}$ & 0.926 & 15.01 & 0.44 \\
\hline Compound & $\widehat{\hat{y}}=\mathbf{1 6 . 7 5 4} * \mathbf{1 . 7 1 4 ^ { \mathrm { x } }}$ & $\mathbf{0 . 9 3 3}$ & $\mathbf{0 . 0 9 4}$ & $\mathbf{0 . 3 0}$ \\
\hline Exponential & $\widehat{y}=2.819 \mathrm{e}^{(0.539 \mathrm{x})}$ & 0.911 & 0.091 & 0.75 \\
\hline
\end{tabular}

$\mathrm{y}=$ sugar production

$\mathrm{x}=$ sugarcane area

Table.2 Statistical models for predicting the sugar production in India

\begin{tabular}{|c|c|c|c|c|}
\hline Model & Equation & $\mathbf{R}^{2}$ & $\begin{array}{c}\text { Standard } \\
\text { error }\end{array}$ & RMSE \\
\hline Linear & $\widehat{y}=-170.461+1.198 x$ & 0.904 & 0.104 & 0.15 \\
\hline Logarithmic & $\widehat{y}=-1759.29+342.175 \log (x)$ & 0.882 & 0.15 & 15.82 \\
\hline Growth & $\widehat{y}=e^{(3.169+0.0067 x)}$ & 0.892 & 0.103 & 0.17 \\
\hline Cubic & $\widehat{y}=36.082-0.260 x+0.001 x^{2}+0.0000027 x^{3}$ & 0.916 & 0.103 & 0.10 \\
\hline Quadratic & $\widehat{y}=101.158-0.689 x+0.0032 x^{2}$ & 0.916 & 0.11 & 18.99 \\
\hline Compound & $\widehat{y}=23.802 * 1.00678^{x}$ & 0.892 & 0.11 & 16.41 \\
\hline Exponential & $\widehat{y}=23.802 \mathrm{e}^{(0.0067 \mathrm{x})}$ & 0.892 & 0.11 & 15.01 \\
\hline
\end{tabular}

$\mathrm{y}=$ sugar production

$\mathrm{x}=$ sugarcane production

Fig.1 Expected sugar production using compound model based on sugarcane area

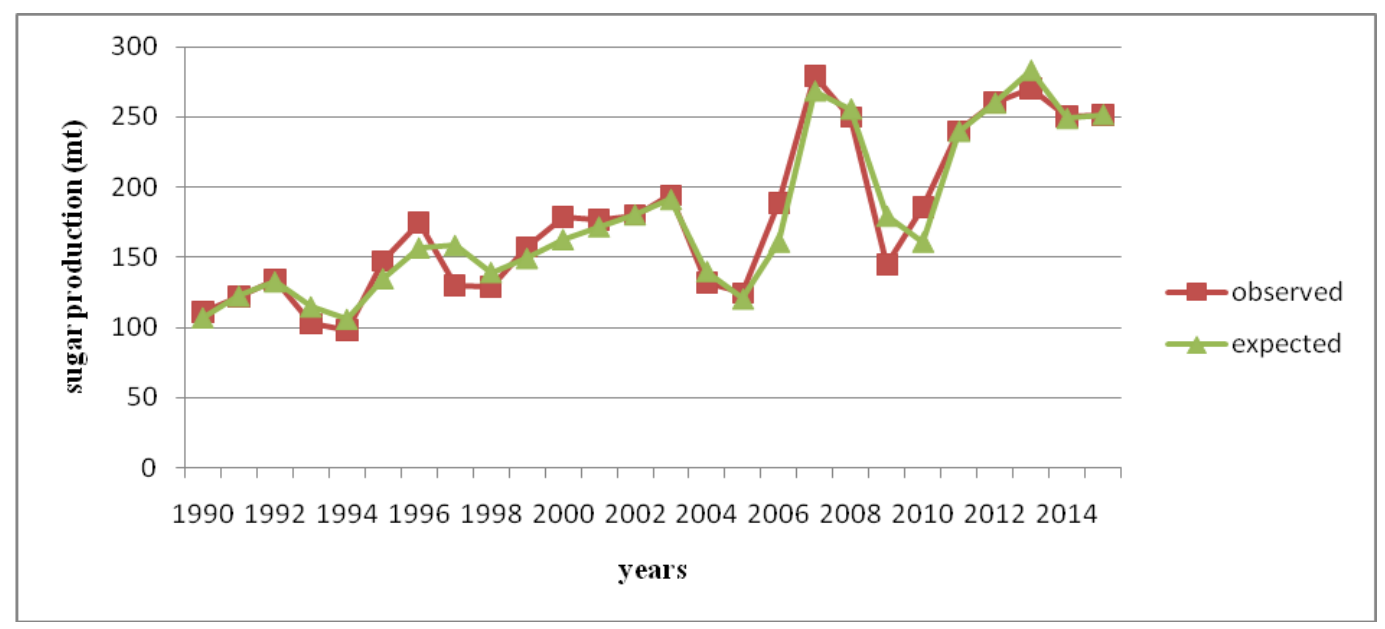


Fig.2 Expected sugar production using cubic model based on sugarcane production

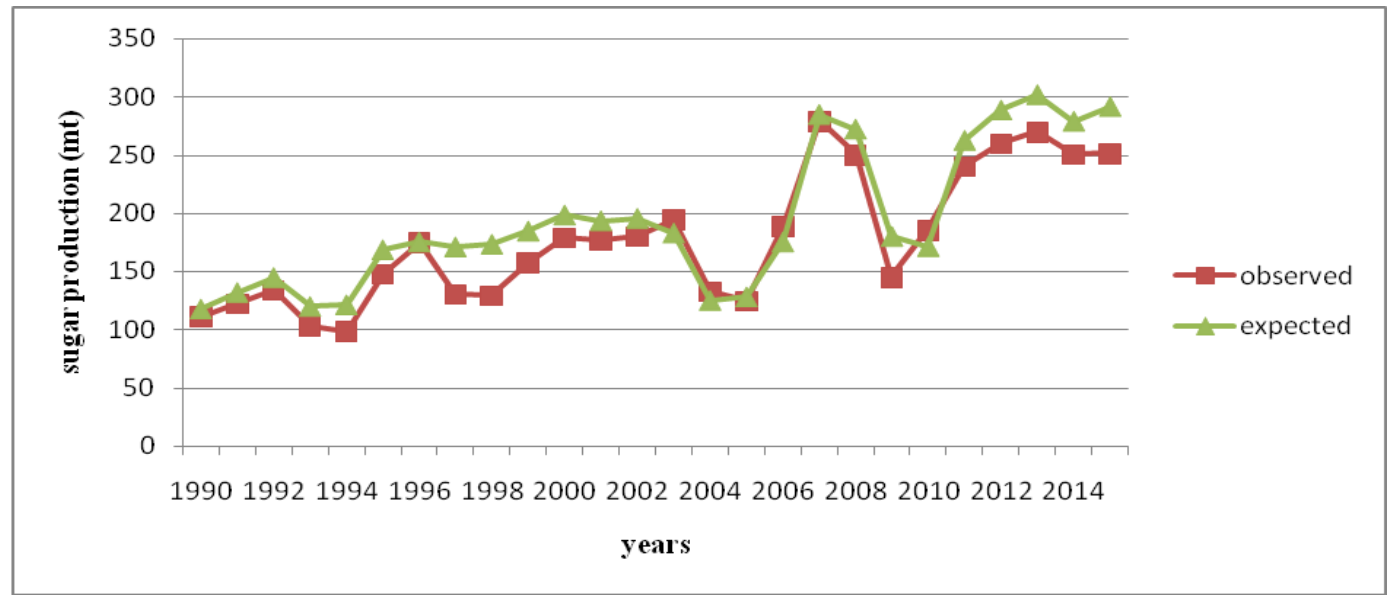

Cubic model $\widehat{y} \quad=36.082$ $0.260 \mathrm{x}+0.001 \mathrm{x}^{2}+0.0000027 \mathrm{x}^{3}$

$\mathrm{y}=$ sugar production.

$\mathrm{x}=$ sugarcane area.

The results were in line with work done by Suresh (2013), who conducted research on the spatial analysis of influence of climate on chilli in Dharwad, Gadag and Haveri districts was conducted based on secondary data. Models were built in order to predict yield with the help of individual weather parameter.

The cubic model was found to be significant and best suited for the trend of rainfall, temperature and relative humidity of selected districts, followed by quadratic model.

\section{References}

Chikkeshkumar, K. M., 2010. A statistical investigation on association between weather parameters and crop yield in selected districts of Karnataka. M. Sc. (Agri.) Thesis, Univ. Agric. Sci., Dharwad (India).

Neelam, C., Sinha, A. K., Gupta, D. K. and Rajesh, C., 2014. A statistical investigation on different modeling techniques for crop yield influenced by weather parameters in northern hills of Chhattisgarh. Int. J. Agric. Inno. Res., 3(3): 942-947.

Santoshkumar, M. A., 2015. Crop modelling on estimation of yield and yield related parameters in soybean. M. Sc. (Agri.) Thesis, Univ. Agric. Sci., Dharwad (India).

Shruthi, H. D., 2016. Effect of weather parameters and nutrient uptake on production of rabi sorghum -A statistical analysis. M. Sc. (Agri.) Thesis, Univ. Agric. Sci., Dharwad (India).

Suresh, B.L., 2013. Multivariate analysis to study the impact of weather parameters on rain fed crops of Dharwad district, $M$. Sc. (Agri.) Thesis, Univ. Agric. Sci., Dharwad (India).

\section{How to cite this article:}

Megha, J., Y.N. Havaldar, N.L. Pavithra, B.B. Jyoti and Kiran Kumar, V. 2019. Identification of the Best Model for Forecasting of Sugar Production among Linear and Non-linear Model. Int.J.Curr.Microbiol.App.Sci. 8(03): 2556-2560. doi: https://doi.org/10.20546/ijcmas.2019.803.303 